\title{
J.W.B. Sisam retires as Dean of the Faculty of Forestry University of Toronto
}

On June 30,1971, J. W. B. Sisam will complete his 24th year as dean of the Faculty, and on that date will retire from the deanship to continue teaching as a senior professor on the Faculty staff.

Under Dean Sisam's direction, tremendous changes have taken place in the status and orientation of professional education at Toronto. Although the undergraduate course has consistently maintained its general character, subject options were initiated in 1953-54 and since that time have been vastly increased. In 1961-62, the Diploma Course in Resource Management was introduced, and in 1965-66 the Wood Science program was inaugurated.

It is in the field of postgraduate studies, however, that major steps were taken. When Sisam became dean in 1947, there was only one graduate student engaged in an M.Sc.F. program; now, at the time of his retirement, there are over 30 graduate students, five whom are on Ph.D. programs.

In his own education, Sisam graduated from the University of New Brunswick in 1931, obtained his M.Sc.F. magna cum laude, from Yale in 1937, and received an honorary D.Sc. degree from the University of New Brunswick in 1956.

Within his responsibilities as dean of the Faculty, Dr. Sisam has always maintained close contact with the Alumni. In 1949, when interest in the Alumni Association was at a low level, he began a program of activities related to the Association which has developed it into one of the most active in the University of Toronto.

Although actively involved in directing the Faculty, Dr. Sisam has made important contributions to the development of forestry in

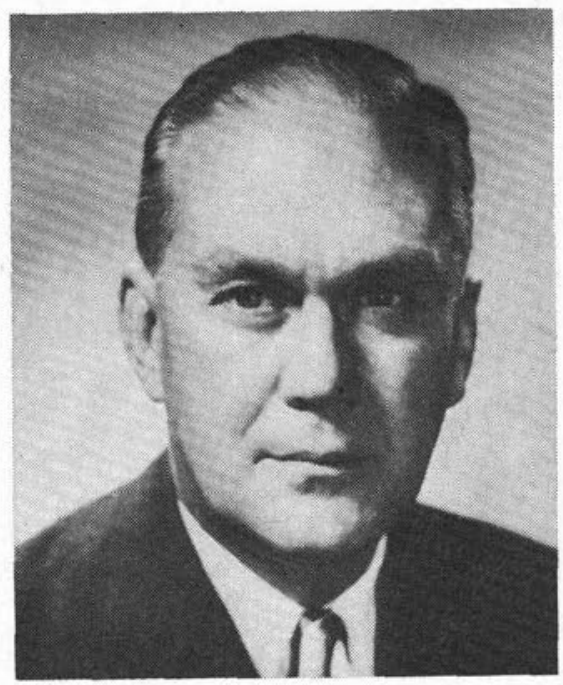

Ontario, in Canada, and in the international sphere. $\mathrm{He}$ was a charter member and first President of the Ontario Professional Foresters Association (1957-59), and Chairman of the Advisory Committee to the Minister of Lands and Forests of Ontario (1952-69). In the latter capacity, he was instrumental in the initiation of many studies relating to the development and programs of that Department. In 1947, in cooperation with the Canadian Forestry Association, Dr. Sisam organized the Ontario Forestry Association, and he became its first president in 1949. His interest in the broader aspects of the use of natural resources was recognized recently when he was elected to the presidency of the Conservation Council of Ontario (1968-).

On the Canadian scene, Dr. Sisam was active in the Canadian Institute of Forestry; he chaired the Southern Ontario Section, and was the national president from 1955 to 1957.

Bernie Sisam's contribution to international forestry commenced in 1939 when he became Director of the Imperial Forestry Bureau, Oxford. Later, while Dean at Toronto, he held and indeed still holds strong ties with the Food and Agricultural Organization of the United Nations, in which he is Chairman of the Advisory Committee on Forestry Education, and at the present time is closely associated with preparations for the World Consultation on Forestry Education and Training to be held in Stockholm in October.

In addition to his effective contribution to forestry, Dr. Sisam's talents have taken him to positions of responsibility in widely ranging areas of interest. Of particular note are his services to athletics within the University of Toronto. He was president of the Athletic Directorate (1959-63), chairman of the Presidential Advisory Committee on Athletic Programs, and President of the Ontario-Quebec Athletic Association 1958-60 and 1964-66. Other responsibilities within the University which he has held included the chairmanship of the Presidential Advisory Committee on the Institute of Business Administration, of the Senate Committee on Applications and Memorials, and of the Devonshire House Committee.

His wide-ranging and highly demanding administrative responsibilities have not prevented Dr. Sisam from making significant contributions to the forestry literature. His papers on forestry range from the use of aerial surveys in forestry and agriculture to the establishment of vegetation on industrial waste land and the world geography of forest resources. He has, in addition, provided a readable and valuable history of forestry at Toronto through his book, Forestry Education at Toronto.

In retiring from the deanship in 1971, Bernie Sisam leaves with the sincere good wishes of those with whom he has worked and with the deep hope that his talents will continue to be directed towards the needs of forestry.

D.V.L. 